\title{
APLIKASI DAGING ANALOG BERBAHAN DASAR UMBI KIMPUL (Xanthosoma sagittifolium) DAN ISOLAT PROTEIN KEDELAI PADA PEMBUATAN SOSIS
}

\author{
Triana Lindriati, Ardiyan Dwi Masahid, dan Ike Khasanatut Daroini \\ Jurusan Teknologi Hasil Pertanian, Fakultas Teknologi Pertanian,Universitas Jember \\ E-mail: lindriatitriana@unej.ac.id
}

\begin{abstract}
ABSTRAK
Sosis merupakan salah satu produk pangan yang biasanya berbahan dasar daging. Pengembangan sosis dan daging analog berbahan umbi kimpul (Xanthosoma sagittifolium) dan isolat protein kedelai berpotensi menyediakan sosis sehat. Penelitian ini bertujuan untuk mengetahui pengaruh penambahan daging analog dengan perbandingan jumlah daging analog dan daging ayam yang ditambahkan dalam pembuatan sosis terhadap karakteristik organoleptik, fisik dan kimia sosis. Parameter yang dianalisis adalah organoleptik ( warna, rasa, tekstur, aroma dan keseluruhan), fisik (warna, tekstur dan kenampakan irisan) dan kimia (kadar air, abu, lemak, protein dan karbohidrat). Hasil penelitian menunjukkan bahwa penambahan daging analog berpengaruh nyata terhadap parameter fisik, kimia serta organoleptik. Sampel yang memiliki nilai organoleptik mendekati 100\% daging ayam, yang dilihat dari sifat organoleptik seperti warna, rasa, aroma, tekstur, kenampakan serta keseluruhan yaitu sampel dengan penambahan daging analog sebesar $25 \%$ dan $50 \%$. Sosis yang dihasilkan secara keseluruhan memiliki warna dengan kecerahan sebesar 59,63 - 65,63, tekstur sebesar 48,85\%-60,8\%, kadar air sebesar 56,09\%-57,18\%, kadar abu sebesar 0,92\%-1,23\%, kadar protein sebesar 15,22\%$26,5 \%$, kadar lemak sebesar 12,89\%-17,91\% dan kadar karbohidrat sebesar 3,27\%-8,76\%.

Kata kunci-daging analog; isolat protein kedelai; sosis; umbi kimpul
\end{abstract}

\section{PENDAHULUAN}

Sosis merupakan salah satu produk pangan yang umumnya berbahan dasar daging sapi atau ayam maupun ikan yang digiling dan dicampur dengan bumbu dan dimasukkan ke dalam selongsong. Bahan tambahan yang digunakan adalah lemak dan air yang digunakan dalam proses emulsifikasi (Koswara, 2009). Sosis dengan bahan dasar daging jika dikonsumsi berlebihan memiliki dampak negatif bagi kesehatan. Dampak negatif dari sumber protein hewani ini dikarenakan memiliki kandungan kolesterol yang tinggi sehingga dapat meningkatkan resiko penyakit jantung koroner (Suryati, 2010). Oleh karena itu bagi penderita penyakit degeneratif akan beralih pada produk vegetarian untuk menghindari konsumsi daging. Salah satu sumber protein nabati yang dapat menggantikan daging asli dan dapat memenuhi kebutuhan protein yaitu daging analog.

Menurut Rareunrom dkk. (2008), daging analog dibuat dari isolat protein kedelai melalui proses ekstruksi. Pembuatan daging analog memerlukan penambahan sumber karbohidrat. Kandungan karbohidrat memegang peranan penting dalam pembentuk struktur serat, semen bagi matrik proteinprotein sehingga dapat meningkatkan kekerasan daging tiruan. Salah satu sumber yang dapat digunakan adalah tepung umbi kimpul. Xanthosoma sagittifolium memiliki kandungan gizi yang terkandung dalam 100 gram kimpul segar terdapat 2,81 g protein, 0,08 g lemak, dan 28,66 g karbohidrat, 0,56 g serat kasar, 1,31 g serat pangan larut air, 0,99 g PLA dan 0,00083 mg/g diosgenin (Jatmiko, 2014). Senanayake et al., (2012) menyatakan bahwa umbi kimpul memiliki kandungan senyawa bioaktif seperti senyawa diosgenin, flavonoid dan saponin yang bermanfaat baik untuk tubuh. Selain itu umbi kimpul juga memiliki indeks glikemik rendah meskipun mengandung karbohidrat cukup tinggi yaitu sekitar 70-80\%.

Penelitian sebelumnya oleh Lindriati dkk. (2018), menunjukkan penambahan tepung umbi porang pada matrik daging tiruan hingga $50 \%$ dapat meningkatkan nilai tekstur dan kadar air, akan tetapi menurunkan kelarutan protein. Selain itu hasil penelitian sebelumnya juga menunjukkan bahwa daging analog dari umbi kimpul lebih bisa diterima konsumen dari pada dari porang serta memiliki sifat fisik yang lebih baik (Lindriati dkk, 2019).

Pembuatan sosis dari umbi kimpul dan isolat protein kedelai diharapkan dapat menghasilkan sosis yang baik untuk kesehatan, serta dapat mengurangi jumlah konsumsi daging. Oleh karena itu dilakukan penelitian untuk mengetahui pengaruh karakteristik sosis dari daging analog dengan 
perlakuan perbandingan jumlah daging analog dan daging ayam yang ditambahkan dalam pembuatan sosis terhadap karakteristik fisik, kimia dan organoleptik produk sosis serta sosis sehingga dihasilkan sosis sehat dan memiliki karakteristik mendekati sosis dari daging.

\section{METODOLOGI PENELITIAN}

\section{A. Lokasi dan Waktu Penelitian}

Penelitian ini dilaksanakan di Laboratorium Rekayasa Proses Hasil Pertanian (RPHP) dan Laboratorium Kimia dan Biokimia Hasil Pertanian (KBHP) serta Laboratorium Enginering Hasil Pertanian Fakultas Teknologi Pertanian Universitas Jember. Waktu penelitian dimulai pada bulan Juli Oktober 2018.

\section{B. Bahan dan Alat}

Bahan yang digunakan dalam penelitian ini yaitu umbi kimpul, Isolat Protein Kedelai (ISP), bumbu-bumbu sosis, dan selongsong sosis. Bahan yang digunakan dalam analisis adalah aquades, larutan blanko, alkohol, aluminium foil, asam klorida $(\mathrm{HCl})$, natrium hidroksida $(\mathrm{NaOH})$, asam borat $\left(\mathrm{H}_{2} \mathrm{BO}_{3}\right)$, heksan, selenium, asam sulfat $\left(\mathrm{H}_{2} \mathrm{SO}_{4}\right)$ dan indikator MMMB.

Alat yang digunakan dalam penelitian meliputi, oven, ayakan Tyler 60 mesh, food prosessor (Phillip), kompor, peralatan gelas (glassware), eksikator, neraca analitik (Ohaus), textur analyzer (merk SD-700), colour reader (merk CR-10), Buchi K-355, labu kejdahl, cawan porselen, soxhlet Buchi, tanur pengabuan Nabertherm, ekstruder, alat pengukus, freezer.

\section{Rancangan Penelitian}

Rancangan percobaan yang digunakan pada proses pembuatan sosis adalah Rancangan Acak Lengkap (RAL) yaitu yang terdiri dari satu faktor yaitu perbedaan formulasi daging $0 \%$ (A1), $25 \%$ (A2), 50\% (A3), 75\% (A4), 100\% (A5). Penelitian di bagi menjadi 2 tahapan. Tahap pertama menentukan perlakuan terbaik berdasarkan uji organoleptik. Tahap ke dua pengukuran parameter fisik dan kimia. Parameter yang diamati warna, tekstur, kenampakan irisan, kadar air, abu, lemak, protein dan karbohidrat.

\section{Pelaksanaan Penelitian}

1. Pembuatan Tepung Kimpul

Tepung kimpul yang diawali dengan pengupasan umbi kimpul1 kg kemudian dilakukan pembersihan (pencucian) yang bertujuan untuk menghilangkan kotoran yang melekat pada bahan, kemudian umbi kimpul diiris dengan alat slicer dan direndam dengan 3 liter air dalam 5 gram larutan garam selama 1 jam yang bertujuan untuk menghilangkan asam oksalat pada umbi kimpul. Irisan umbi kimpul kemudian ditiriskan dan dikering anginkan selama 4 jam kemudian dioven pada suhu $60^{\circ} \mathrm{C}$ selama $24 \mathrm{jam}$. Setelah chips umbi kimpul kering digiling dan diayak dengan ayakan 60 mesh sehingga dihasilkan tepung kimpul yang akan digunakan dalam pembuatan daging analog Suismono (2011).

\section{Pembuatan daging analog}

Pembuatan daging analog dilakukan dengan mencampurkan semua bahan, yaitu tepung kimpul $30 \%$ dan ISP $70 \%$. Proses pencampuran dilakukan secara manual dan dilakukan penambahan air sebanyak $110 \%$. Adonan daging analog tersebut dimasukkan ke dalam ekstruder selama 2 menit untuk mencetak adonan. Adonan yang tercetak dikukus pada suhu $100^{\circ} \mathrm{C}$ selama 30 menit dan dipanaskan menggunakan oven suhu $50^{\circ} \mathrm{C}$ selama 24 jam.

\section{Pembuatan sosis ayam dengan subtitusi daging analog}

Proses awal dalam pembuatan sosis adalah daging ayam dilakukan pencucian dan pemotongan, kemudian daging analog $0 \%$ (A1), 25\% (A2), 50\% (A3), 75\% (A4) dan 100\% (A5) dari daging ayam dilakukan penggilingan untuk menghaluskan daging menggunakan food processror. Pada proses penggilingan dilakukan penambahan tepung tapioka $15 \%$, air es $15 \%$, bawang putih $4 \%$, garam $2 \%$, gula 1,55 , minyak $10 \%$, lada $1 \%$, tapioka $15 \%$, putih telur $6 \%$, STTP $0,05 \%$, dan susu skim $6 \%$ diaduk hingga merata. Adonan yang telah membentuk emulsi stabil dimasukkan kedalam selongsong ukuran $10 \mathrm{~cm}$ menggunakan alat stuffer. Kemudian dilakukan pengukusan selama 45 menit dengan suhu $100^{\circ} \mathrm{C}$. 
Pengukusan bertujuan untuk meningkatkan rasa, menyatukan komponen adonan sosis yang berupa emulsi minyak dalam air membentuk tekstur yang kompak. Proses terakhir dilakukan pendinginan dalam air untuk menurunkan suhu membentuk tekstur yang kompak.

\section{Uji Organoleptik}

Sampel kesukaan panelis dapat diketahui dengan menggunakan uji organoleptik yaitu uji kesukaan yang mengacu pada Setyaningsih dkk (2010). Uji yang digunakan dalam penelitian ini meliputi aroma, warna, tekstur dan kekenyalan dengan menggunakan minimal 30 orang panelis dengan usia sekitar 20 tahun, 12 laki-laki dan 18 perempuan. Cara pengujian dilakukan secara acak dengan menggunakan sampel daging analog yang telah terlebih dahulu diberi kode angka secara acak. Panelis diminta untuk menentukan tingkat kesukaan mereka terhadap sosis yang telah disiapkan. Skor yang diberikan sebagai berikut: 1 = Sangat amat tidak suka; 2 = Sangat tidak suka; 3 = Tidak suka; $4=$ Agak tidak suka; $5=$ Netral; $6=$ Agak suka; $7=$ Suka; $8=$ Sangat suka; $9=$ Amat sangat suka.

\section{Penentuan Perlakuan Terbaik}

Perlakuan terbaik ditentukan berdasarkan kesukaan konsumen. Sampel diuji organoleptik kemudian diambil yang banyak disukai panelis selanjutnya akan diuji lanjut yaitu uji fisik ( warna, tekstur dan kenampakan irisan) dan uji kimia (kadar air, abu, lemak, protein dan karbohidrat).

\section{Warna (Menggunakan Colour Reader tipe CR-10).}

Alat yang digunakan dalam pengukuran warna adalah Colour Reader. Cara kerjanya dari colour reader yaitu pertama menghidupkan tombol on pada colour reader, kemudian menentukan nilai standarisasi dengan cara mengukur warna porselin dengan cara menempelkan secara tegak lurus pada colour reader dan menekan tombol "target" sehingga akan muncul nilai pada layar yaitu L,a, dan $b$. Kemudian sosis yang digunakan dilakukan pembacaan warna dengan cara yang sama dan akan muncul nilai $d E, d L$, dad, dan $d b$. Nilai pada standar porselin yaitu $L=94,35, a=-5,75, b=6,51$, dari nilai tersebut dapat dihitung nilai $\mathrm{L}, \mathrm{a}, \mathrm{b}$ dari sosis menggunakan rumus berikut :

Rumus : $\mathrm{L}=$ standart $\mathrm{L}+\mathrm{dL}$

$$
\begin{aligned}
& \mathrm{a}=\text { standart } \mathrm{a}+\mathrm{da} \\
& \mathrm{b}=\text { standart } \mathrm{b}+\mathrm{db}
\end{aligned}
$$

Nilai L menyatakan parameter kecerahan (lightness) yang mempunyai nilai dari 0 -100 (hitam-putih) (Hutching, 1999).

\section{Tekstur (Menggunakan Rheotex)}

Prosedur pelaksanaan pengujian kekerasan adalah kabel data dari Texture analyzer dipastikan telah tersambung. Jarum penusuk sampel (probe) dipasangdan diatur posisinya sampai mendekati sampel. Probe yang digunakan adalahjenis probe silinder yang mempunyai diameter $1 \mathrm{~cm}$. Selanjutnya yaitu mengatur trigger diformasi 5 gram dan kecepatan $0,50 \mathrm{~m} / \mathrm{s}$. Kemudian tekan tombol start selanjutnya display akan mengeluarkan analisa nilainya.

\section{Kenampakan Irisan (Menggunakan Foto Microskop)}

Proses pengukuran kenampakan irisan menggunakan mikroskop dengan perbesaran 20X yaitu sosis yang digunakan dilakukan pemotongan melintang ke tengah dengan ketebalan 1-3 mm kemudian dipotong dari bagian atas, sosis yang telah dipotong diletakkan pada meja mikroskop, kemudian dilakukan pengamatan dan dilakukan pengambilan gambar.

\section{Analisis Proksimat}

Parameter yang diukur adalah: kadar air, kadar abu, kadar protein, kadar lemak dengan mengacu pada AOAC (2005), sedangkan kadar karbohidrat dihitung dari pengurangan 100\% dari kadar air, abu, protein dan lemak.

\section{E. Analisa Data}

Hasil pengamatan fisik dan kimia diolah menggunakan analisis sidik ragam (ANOVA) Apabila terdapat perbedaan atau pengaruh yang signifikan, maka akan dilanjutkan dengan uji DNMRT. Analisa dilakukan menggunakan program SPSS 16.0 bertaraf kepercayaan $95 \%$. 


\section{HASIL DAN PEMBAHASAN}

\section{A. Organoleptik}

Hasil uji chi-square terhadap kesukaan warna, aroma, rasa, tekstur dan kesukaan keseluruhan sosis daging analog menunjukkan bahwa penambahan daging analog berpengaruh nyata terhadap parameter - parameter tersebut. Hasil pengukuran organoleptik terhadap tingkat kesukaan warna, aroma, rasa, tekstur dan keseluruhan secara berurutan disajikan pada Gambar 1, Gambar 2, Gambar 3, Gambar 4 dan Gambar 5. Pada Gambar1, 2, 3, 4 dan 5 menunjukkan peningkatan persentase daging analog pada adonan sosis ayam menurunkan tingkat kesukaan warna, aroma, rasa, tekstur dan keseluruhan. Hal ini dikarenakan kadungan senyawa fenolik pada tepung kimpul yang mengakibatkan terjadinya proses pencoklatan enzimatis. Hal tersebut mengakibatkan warna daging analog jika diolah menjadi sosis menghasilkan sosis dengan warna lebih gelap dibandingkan sosis dari daging ayam.

Penurunan tingkat kesukaan aroma kemungkinan disebabkan aroma langu dari ISP yang disebut beany flavor yang merupakan hasil reaksi oksidasi ensimatis dari asam linoleat dan lenolenat oleh enzim liposigenase (Ma dan Ames, 1988). Aroma langu pada kedelai ini juga menghambat pengembangan produk olahan kedelai lainnya. Selain itu kandungan senyawa glikosida pada kedelai seperti saponin, sapogenol (Wulandari et al., 2013) dapat menimbulkan rasa pahit. Demikian pula kandungan saponin pada umbi kimpul. Oleh karena itu peningkatan presentase daging analog pada adonan sosis ayam dapat menurunkan nilai kesukaan rasa.

Kandungan kabohidrat yang tinggi pada umbi kimpul dapat meningkatkan kandungan karbohidrat adonan sosis seiring dengan peningkatan presentase daging analog. Hal ini dapat meningkatkan jumlah air yang terserap dalam matrik sosis sehingga mempengaruhi tekstur sosis yang dihasilkan. Tekstur sosis yang bermutu baik adalah yang memiliki tekstur kompak, kenyal dan empuk. Kualitas sosis yang baik ditentukan oleh daya ikat protein dan bahan yang ditambahkan (Koapaha et al., 2011). Protein hewani lebih mampu membentuk jaringan matrik dibanding protein nabati oleh karena itu penurunan kadar protein hewani dapat menurunkan tekstur sosis.

Penurunan tingkat kesukaan warna, aroma, rasa, tekstur seiring dengan peningkatan presentase daging analog dapat menurunkan nilai kesukaan keseluruhan. Menurut Tanjung dkk (2016), menyatakan bahwa penilaian keseluruhan merupakan gabungan dari apa yang dilihat, apa yang diraba dan apa yang dirasa.

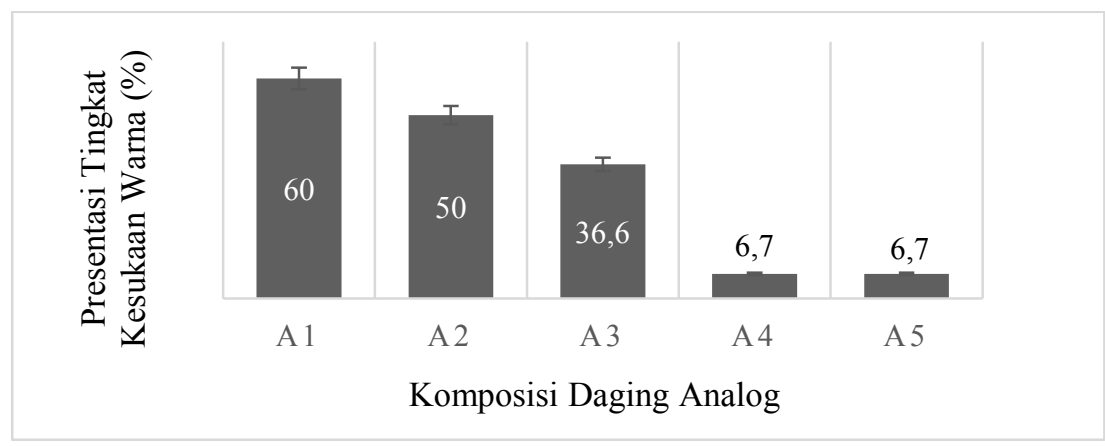

Gambar 1. Presentase tingkat kesukaan warna sosis daging analog

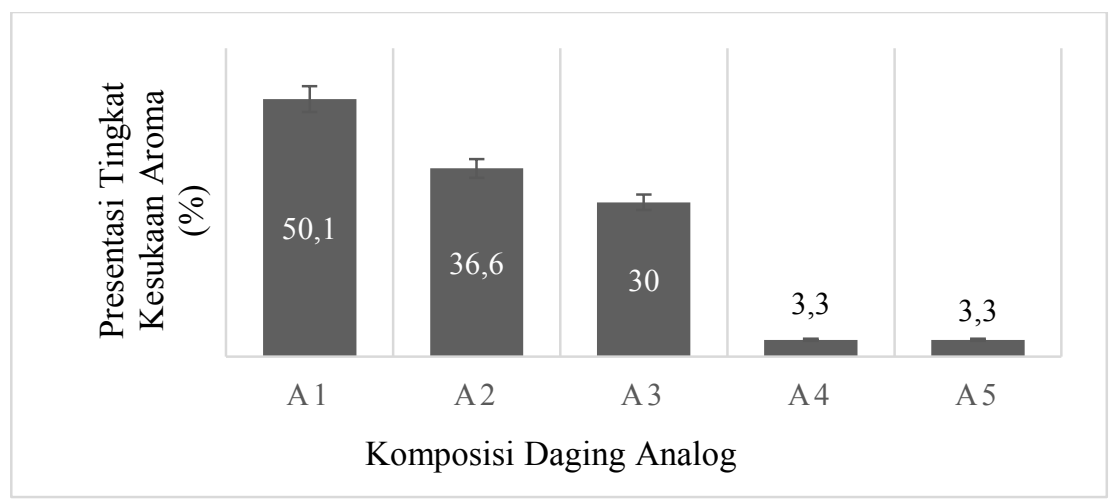

Gambar 2. Presentase tingkat kesukaan aroma sosis daging analog 


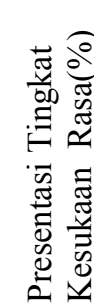

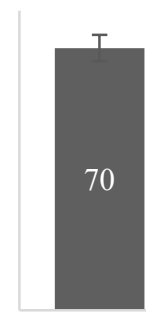

A 1

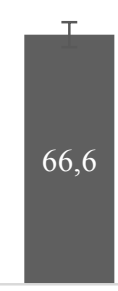

A 2

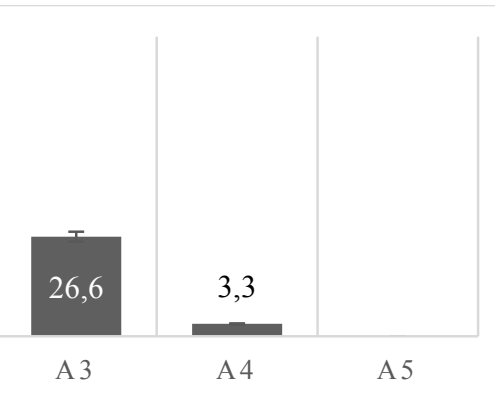

Komposisi Daging Analog

Gambar 3. Presentase tingkat kesukaan rasa sosis daging analog

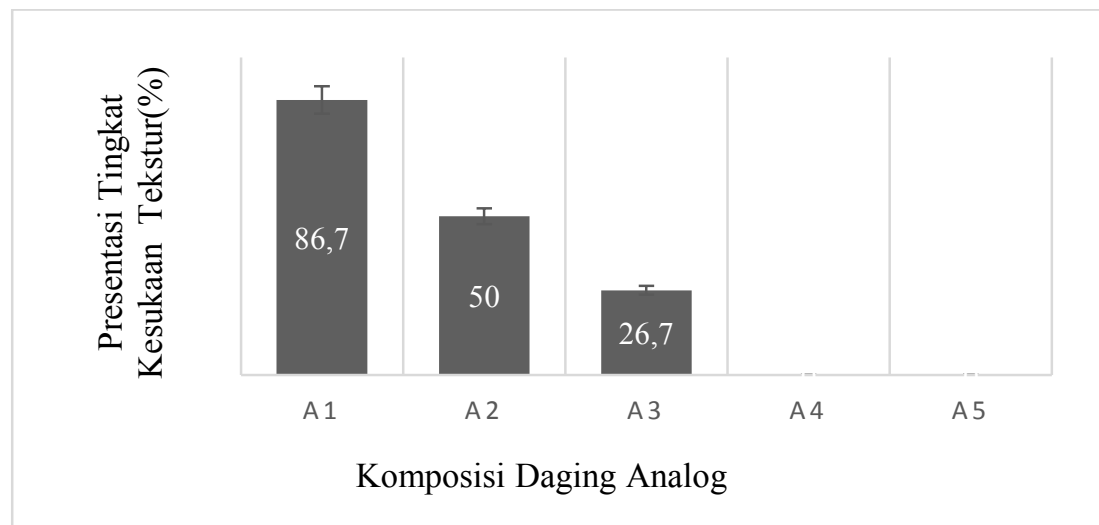

Gambar 4. Presentase tingkat kesukaan tekstur sosis daging analog

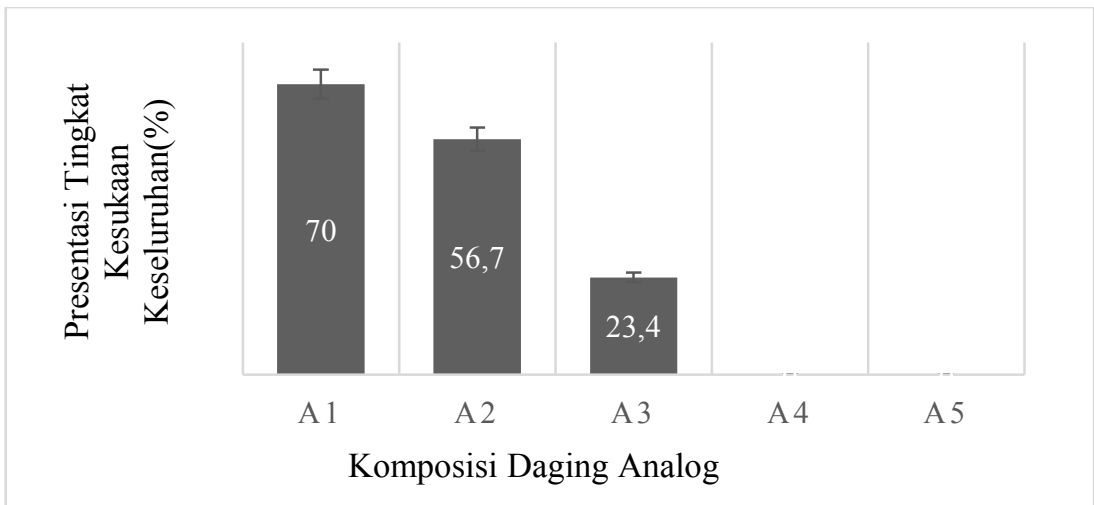

Gambar 5. Presentase tingkat kesukaan keseluruhan sosis daging analog

Pada penelitian ini sample sosis daging analog yang akan dilakukan pengukuran sifat fisik dan kimia adalah sample yang memiliki nilai skor organoleptik mendekati sosis daging ayam tanpa penambahan daging analog, hal ini disebabkan karena sample tanpa penambahan daging analog yang memiliki nilai kesukaan konsumen paling tinggi. Hasil skor persentase organoleptik pada Tabel 1.

Tabel 1. Penentuan sample yang aakan diuji fisik dan kimia

\begin{tabular}{ccccccc}
\hline Sampel & Warna & Aroma & Rasa & Tekstur & Keseluruhan & Total \\
\hline A1 & 67,7 & 83,4 & 96,7 & 83,3 & 96,7 & 427,8 \\
A2 & 63,3 & 56,6 & 89,9 & 70 & 66,6 & 346,7 \\
A3 & 63,3 & 46,7 & 53,3 & 53,4 & 80,1 & 296,8 \\
A4 & 23,4 & 16,6 & 20 & 13,3 & 6,6 & 79,9 \\
A5 & 16,7 & 10 & 0 & 10 & 13,4 & 50,1 \\
\hline
\end{tabular}


Berdasarkan Tabel 1 sampel A2 dan A3 memiliki tingkat peneriman konsumen mendekati perlakuan A1. Hal ini menunjukkan penambahan daging analog hingga 50\% menghasilkan sosis yang masih dapat diterima konsumen mendekati sosis $100 \%$ daging ayam. Pengamatan lebih lanjut adalah pengukuran parameter fisik dan kimia terhadap perlakuan A1, A2 dan A3 untuk mengetahui pengaruh penambahan daging analog pada warna, tekstur dan kenampakan irisan sosis yang dihasilkan.

\section{B. Sifat Fisik}

Hasil sidik ragam dengan taraf kepercayaan 95\% menunjukkan bahwa perlakuan penambahan daging tiruan dari $0 \%$ (A1), 25\% (A2) dan 50\% (A3) berpengaruh nyata terhadap tingkat lightness dan nilai tekstur sosis.

\section{Warna (Lighness)}

Gambar 6 menunjukkan semakin besar variasi subtitusi daging analog, nilai kecerahan sosis ayam semakin kecil yang berarti warna sosis semakin gelap. Hal ini dikarenakan umbi kimpul memiliki kadungan senyawa fenolik yang mengakibatkan terjadinya proses pencoklatan enzimatis. Hal tersebut mengakibatkan warna daging analog menjadi gelap sehingga semakin besar presentase penambahannya akan membuat produk sosis yang dihasilkan semakin gelap. Hal inilah yang mempengaruhi nilai warna yang dihasilkan.

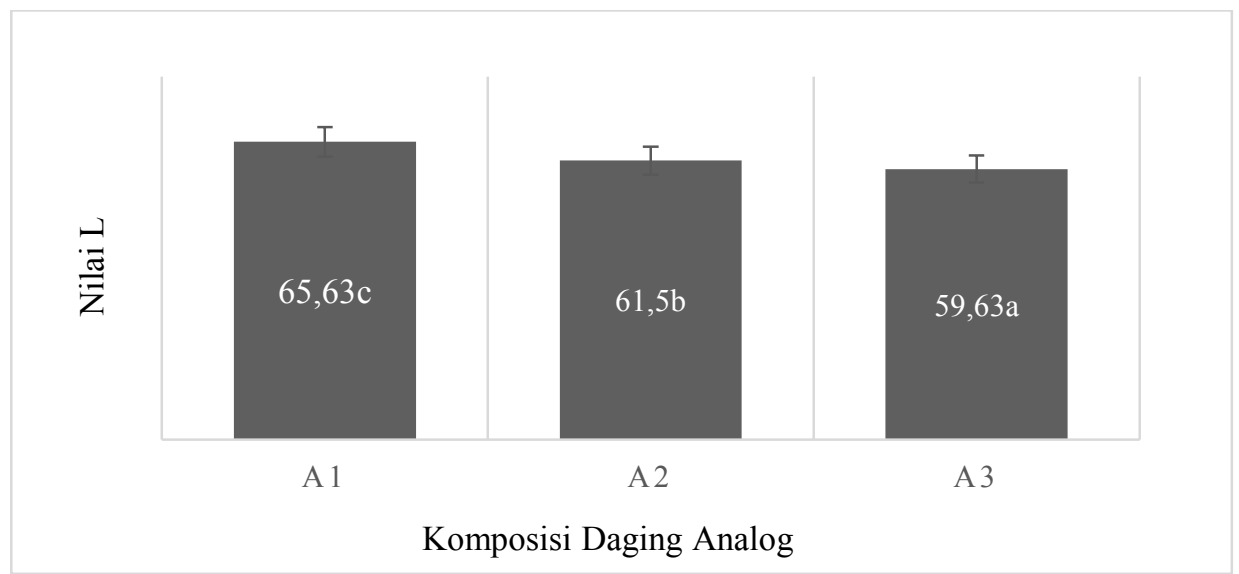

Gambar 6. Nilai warna sosis dengan variasi subtitusi daging analog

\section{Tekstur}

Gambar 7 menunjukkan bahwa tekstur mengalami kenaikan. Hal ini dikarenakan struktur daging analog terbentuk karena adanya interaksi-interaksi protein yang berinteraksi membentuk rongga jaringan. Karbohidrat berperan untuk mengisi rongga-rongga yang terbentuk. Kandungan karbohidrat yang terlalu banyak justru akan menganggu pembentukan matrik protein-protein yang dapat menyebabkan tekstur menjadi lunak (Lindriati, 2018). Peningkatan komposisi daging analog dapat meningkatkan kandungan karbohidrat pada sosis.

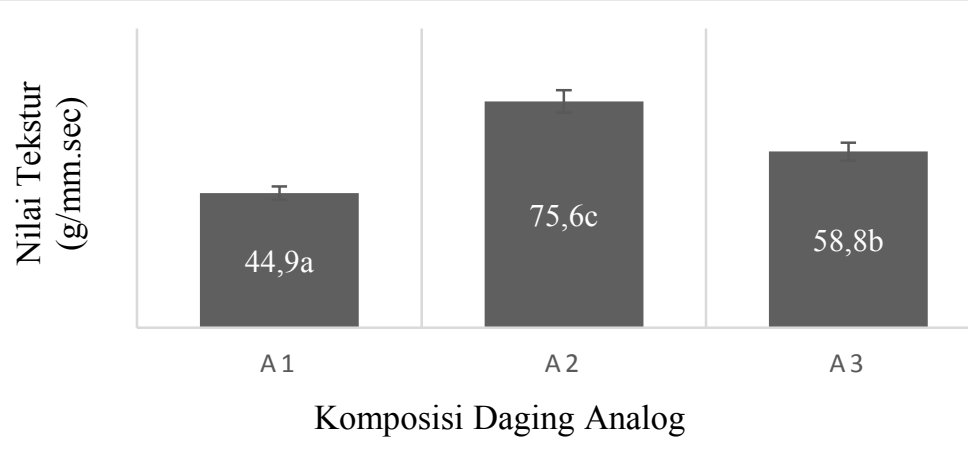

Gambar 7. Nilai tekstur sosis dengan variasi subtitusi daging analog 


\section{Kenampakan Irisan}

Kenampakan irisan diamati dengan metode photo mikroskop dengan perbesaran 4 kali. Kenampakan irisan dapat dilihat pada Gambar 8. Gambar 8 menunjukkan bahwa 25\% analog memiliki pori-pori yang halus karena matrik terisi daging analog. Hal ini sesuai dengan hasil pengukuran tekstur yang menunjukkan titik optimum pada $25 \%$ daging analog. Sedangkan $50 \%$ pori-porinya lebih renggang. Menurut Winarno (2004), kandungan karbohidrat yang tinggi akan cepat mengalami retrogradasi ketika proses pendinginan sosis ketika dimasak.

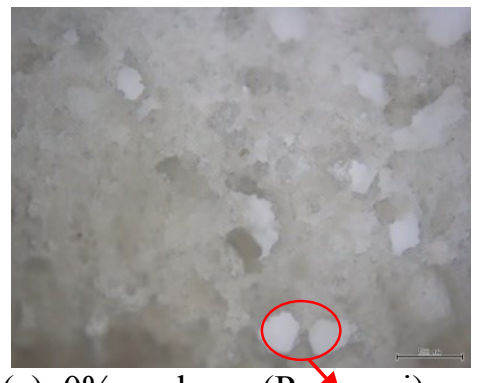

(a) $0 \%$ analog (Port-pori)

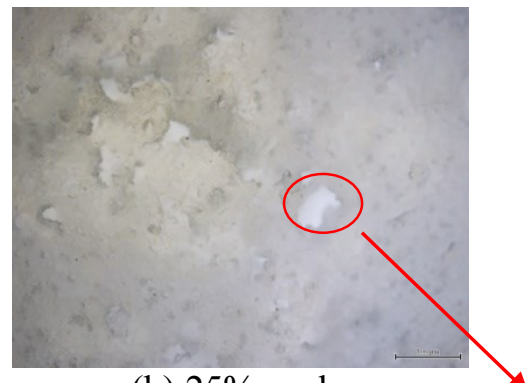

(b) $25 \%$ analog

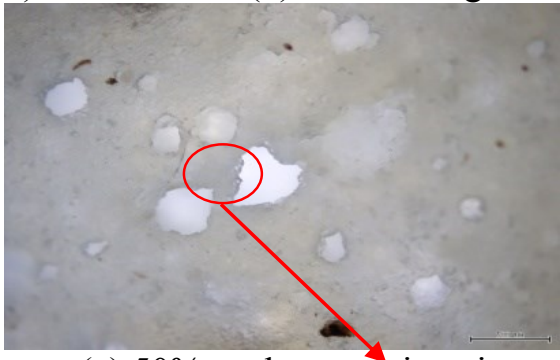

Pori-pori

(c) $50 \%$ analog pori-pori

Gambar 8. Kenampakan irisan sosis

\section{Sifat Kimia}

Hasil analisis sidik ragam menunjukkan bahwa penambahan daging analog pada adonan sosis daging ayam dari $0 \%$ ke $25 \%$ dan $50 \%$ berpengaruh nyata pada perubahan nilai kadar air, kadar abu, kadar protein, kadar lemak dan kadar karbohidrat. Data hasil pengukuran selengkapnya dapat dilihat pada Gambar 9, Gambar 10, Gambar 11, Gambar 12 dan Gambar 13.

\section{Kadar Air}

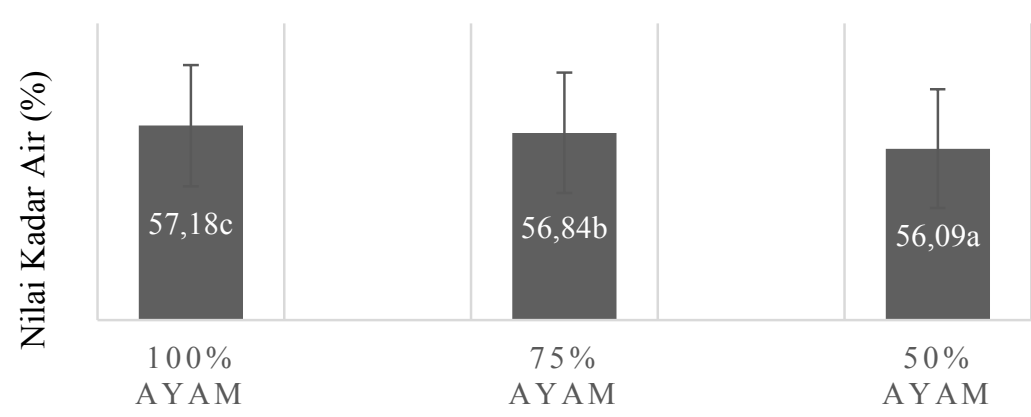

Komposisi Daging Analog

Gambar 9. Nilai kadar air sosis dengan variasi subtitusi daging ayam dan daging analog

Gambar 9 menunjukan rata-rata kadar air tertinggi diperoleh dari perlakuan $0 \%$ daging analog, sedangkan nilai rata-rata terendah diperoleh dari perlakuan 50\% daging analog. Hal ini dikarenakan isolat protein kedelai berbentuk tepung demikian pula tepung umbi gembili, yang memiliki kandungan air yang rendah sehingga dapat menurunkan kadar air sosis. Kadar air sosis daging ayam maksimal menurut SNI adalah $67,0 \%$, pada penelitian ini memenuhi syarat tersebut. 


\section{Kadar Abu}

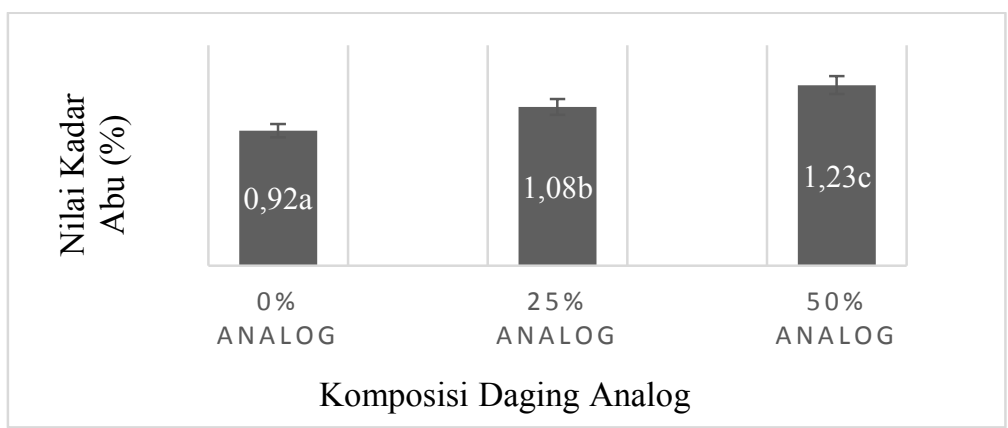

Gambar 10. Nilai kadar abu sosis dengan variasi subtitusi daging ayam dan daging analog

Gambar 10 menunjukkan nilai rata-rata tertinggi kadar abu sosis diperoleh dari perlakuan $50 \%$ daging analog, sedangkan nilai terendah diperoleh dari perlakuan $0 \%$ daging analog. Semakin banyak subtitusi daging analog semakin meningkat kadar abu. Hal ini sesuai dengan SNI 01- 3820-1995, disebutkan bahwa kadar abu yang terkandung dalam sosis tidak boleh melebihi $3 \%$.

\section{Kadar Protein}

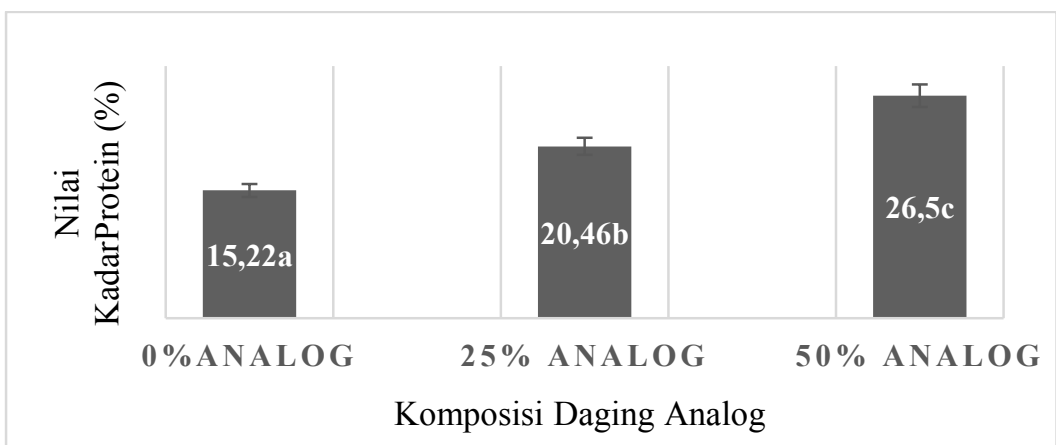

Gambar 11. Nilai kadar protein sosis dengan variasi subtitusi daging ayam dan daging analog

Gambar 11 menunjukkan nilai rata-rata tertinggi kadar protein sosis diperoleh dari perlakuan $50 \%$ daging analog, sedangkan nilai terendah diperoleh dari perlakuan $0 \%$ daging analog. Penelitian sebelumnya melaporkan bahwa peningkatan konsentrasi penambahan isolat protein kedelai akan meningkatkan kadar protein secara signifikan (Kang et al., 2016). Isolat protein kedelai sangat baik untuk memperkaya kandungan protein makanan, sebagai bahan pengikat dan pengemulsi produk olahan daging restrukturisasi, sehingga semakin banyak daging analog maka semakin tinggi kandungan protein. Isolat protein kedelai merupakan protein kedelai dalam bentuk paling halus yang digunakan dalam produk olahan daging. Isolat protein kedelai mengandung lebih dari $90 \%$ protein (Soy Protein Council, 1987). Hal inilah yang menyebabkan sosis modifikasi daging analog memiliki kandungan protein lebih tinggi dibandingkan dengan formulasi $100 \%$ ayam.

\section{Kadar Lemak}

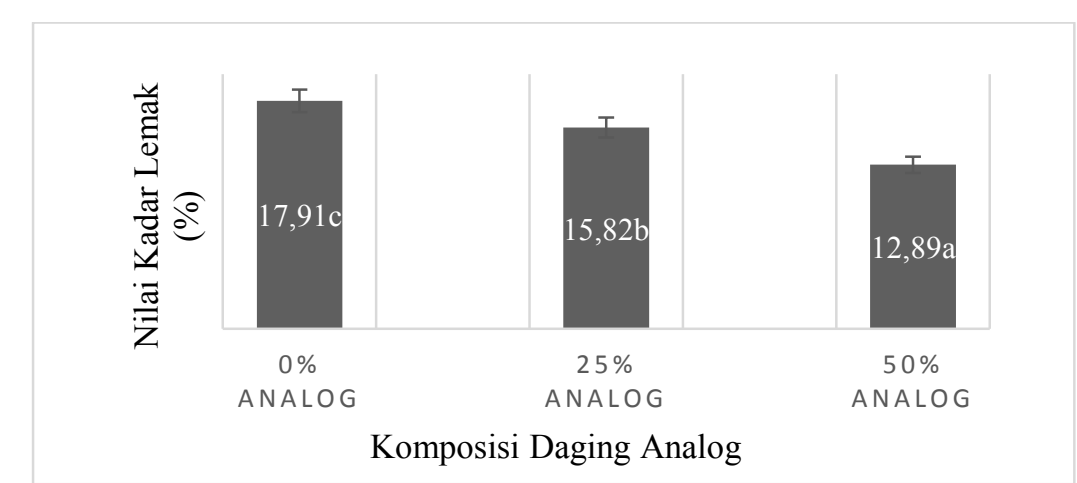

Gambar 12. Nilai kadar lemak sosis dengan variasi subtitusi daging ayam dan daging analog 
Berdasarkan Gambar 12 menunjukkan nilai rata-rata tertinggi kadar lemak sosis diperoleh dari perlakuan $0 \%$ daging analog, sedangkan nilai terendah diperoleh dari perlakuan $50 \%$ daging analog. Hal ini sesuai dengan literatur Widodo (2008) isolat protein kedelai memiliki kemampuan mencegah penyerapan minyak yang berlebihan yang dapat menyebabkan isolat protein kedelai dapat terdenaturasi oleh panas membentuk semacam lapisan pada permukaan bahan sehingga menghalangi masuknya lemak.Kadar lemak maksimal sosis daging ayam menurut SNI 01-3820-1995 adalah 25\%. Hal ini menunjukkan bahwa sosis dengan subtitusi daging analog memenuhi syarat mutu yang telah ditetapkan oleh SNI.

\section{Kadar Karbohidrat}

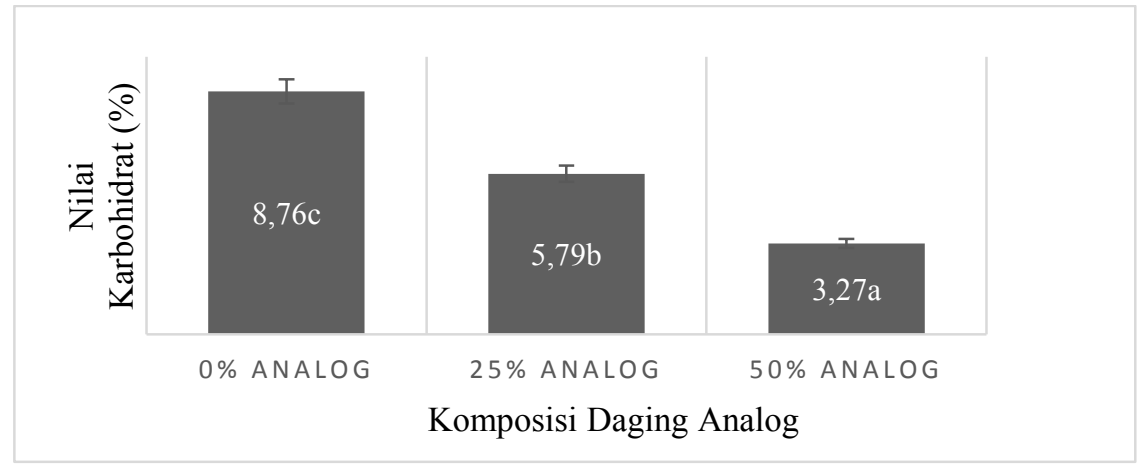

Gambar 13. Nilai kadar karbohidrat sosis dengan variasi subtitusi daging ayam dandaging analog

Berdasarkan Gambar 13 menunjukkan nilai rata-rata tertinggi kadar karbohidrat sosis diperoleh dari perlakuan $0 \%$ daging analog, sedangkan nilai terendah diperoleh dari perlakuan $50 \%$ daging analog. Hal ini dikarenakan daging analog memiliki peningkatan protein yang tinggi yaitu sebesar $26,5 \%$ dibandingkan daging ayam yaitu 15,22 \%. Sehingga peningkatan komposisi daging analog meningkatkan kadar protein hal tersebut menurunkan kadar karbohidrat.

\section{KESIMPULAN}

Penambahan daging analog berbahan dasar umbi kimpul dan Isolat Protein Kedelai (IPK) pada pembuatan sosis daging ayam berpengaruh nyata terhadap parameter penelitian, meliputi karakteristik organoleptik, fisik dan kimia. Sosis yang paling disukai konsumen adalah yang terbuat dari $100 \%$ daging ayam, diikuti dengan $25 \%$ dan $50 \%$ substitusi daging tiruan. Sosis ini memiliki kadar air 56,9\% - 57,18\%, kadar abu 0,92\% - 1,23\%, kadar protein 15,22\% - 26,5\%, kadar lemak 12,89\% - 17,91\%, dan kadar karbohidrat 3,27\% - 8,76\%. Walaupun menurunkan kesukaan konsumen penambahan daging analog pada pembuatan sosis dapat meningkatkan kandungan protein dan menurunkan kandungan lemak sehingga menghasilkan sosis yang sehat. Pada penambahan daging analog hingga $25 \%$ dapat menghasilkan sosis dengan tekstur paling kompak.

\section{DAFTAR PUSTAKA}

Badan Standardisasi Nasional, 1995. Standar Nasional Indonesia. SNI 01-3820- 1995. Sosis. Jakarta: Badan Standardisasi Nasional.

Jatmiko, G. P. 2014. Mie dari Umbi Kimpul (Xanthosoma sagittifolium): Kajian Pustaka. Noodles from cocoyam (Xanthosoma sagittifolium). Jurnal Pangan dan Agroindustri. Vol 2 No.2 p. 127-134.

Koapaha, T., Langi, T., dan Lalujan, L. E. 2011. Penggunaan Pati Sagu Modifikasi Fosfat Terhadap Sifat Organoleptik Sosis Ikan Patin (Pangasius hypophtalmus). Jurnal Ilmiah.Vol. 17(1): 80-85.

Koswara, S. 2009. Teknologi Praktis Pengolahan Daging. Diterbitkan. eBook Pangan.com.http://tekpan.unimus.ac.id/wpcontent/uploads/2013/0 Teknologi Pengolahan Daging Teori dan Praktek.pdf. [18 April 2018]

Lindriati, T. 2018. Teknologi Ekstruksi dalam Pengolahan Pangan. Jember: Caramedia communication. 
Lindriati, T., Herlina dan Emania, J.N., 2018. Sifat fisik daging analog berbahan dasar campuran tepung porang (Amorphopallus oncophyllus) dan isolat protein kedelai. Jurnal Teknologi Pertanian Andalas vol 22 no 2: $175-186$.

Lindriati, T., Lusianti, Herlina, 2019. Developing meat extender properties by addition of taro (Xanthosoma Sagitifolium) or Konjac (Amorphophallus oncophillus) Flour on isolated soy protein extrudate. Makalah telah dipresentasikan pada International Conference on Susteinable Agriculture and Biosystem, $12-13$ November, Padang.

Ma, L. G., Ames, J. 1988. Soy Flavor and Its Improvement. J. Food Sci Nutr. 27, 219-400.

Pratama, R., I., Rostini, I., Liviawaty, E. 2014. Karakteristik Biskuit dengan Penambahan Tepung Tulang Ikan Jangius (Istiophorus Sp) Artikel Penelitian Universitas Padjajaran. Sumedang.

Rareunrom, K., Tonga, S., dan Yongsawatnigul, J. 2008. Effects of Soy Protein Isolate on Chemical and Physical Characteristics of Meat Analog. As. J Food Ag-Ind, 1 (02), 97-104.

Suismono. 2011. Teknologi Pembuatan Tepung dan Pati Ubi-Ubian untuk Menunjang Ketahanan Pangan. Majalah Pangan Vol. X No. 37: 37-49. Jakarta : Puslitbang Bulog.

Suryanti, E. 2010. Perbedaan Rerata Kadar Kolesterol Antara Penderita Angina Pektoris Tidak Stabil, Infark Miokard Tanpa Stelevasi, dan Infark Miokard dengan ST-Elevasi Pada Serangan Akut. Universitas Muhammadiyah Surakarta. Surakarta.

Soy Protein Council, 1987. Soy Protein Products: Characteteristics, Nutritional Aspects and Utilization. Washington, DC.

Tanjung, R., Hamzah, F. dan Efendi, R., 2016. Lama fermentasi terhadap mutu teh daun sirsak (Annona muricata L.). JOM Faperta UR vol 3 no $2: 1-9$.

Widodo, S.A. 2008. Karakteristik Sosis Ikan Kurusi (Nemipterus nematophorus) dengan Penambahan Isolat Protein Kedelai dan Karagenan Pada Penyimpanan Suhu Chilling Dan Frezing. Skripsi. Fakultas Teknologi Perikanan, Institut Pertanian Bogor. Bogor

Winarno F. G. 2004. Kimia Pangan dan Gizi. Jakarta: Gramedia Pustaka Utama.

Wulandari, D., Komar, N., dan Hadi, S. 2013. Perekayasaan Pangan Berbasis Produk Lokal Indonesia (Studi Kasus Sosis Berbahan Baku Kedelai). Fakultas Teknologi Pertanian. Universitas Brawijaya Malang. 